\title{
Performance of Sorghum Varieties under Variable Rainfall in Central Tanzania
}

\author{
Barnabas M. Msongaleli, ${ }^{1}$ S. D. Tumbo, ${ }^{2}$ N. I. Kihupi, ${ }^{2}$ and Filbert B. Rwehumbiza ${ }^{3}$ \\ ${ }^{1}$ Department of Geography and Environmental Studies, University of Dodoma, P.O. Box 395, Dodoma, Tanzania \\ ${ }^{2}$ Department of Engineering Sciences and Technology, Sokoine University of Agriculture, P.O. Box 3003, Morogoro, Tanzania \\ ${ }^{3}$ Department of Soil and Geological Sciences, Sokoine University of Agriculture, P.O. Box 3008, Morogoro, Tanzania \\ Correspondence should be addressed to Barnabas M. Msongaleli; bmsongaleli@yahoo.co.uk
}

Received 30 January 2017; Revised 17 March 2017; Accepted 4 April 2017; Published 27 April 2017

Academic Editor: Jerry Hatfield

Copyright (c) 2017 Barnabas M. Msongaleli et al. This is an open access article distributed under the Creative Commons Attribution License, which permits unrestricted use, distribution, and reproduction in any medium, provided the original work is properly cited.

Rainfall variability has a significant impact on crop production with manifestations in frequent crop failure in semiarid areas. This study used the parameterized APSIM crop model to investigate how rainfall variability may affect yields of improved sorghum varieties based on long-term historical rainfall and projected climate. Analyses of historical rainfall indicate a mix of nonsignificant and significant trends on the onset, cessation, and length of the growing season. The study confirmed that rainfall variability indeed affects yields of improved sorghum varieties. Further analyses of simulated sorghum yields based on seasonal rainfall distribution indicate the concurrence of lower grain yields with the 10-day dry spells during the cropping season. Simulation results for future sorghum response, however, show that impacts of rainfall variability on sorghum will be overridden by temperature increase. We conclude that, in the event where harms imposed by moisture stress in the study area are not abated, even improved sorghum varieties are likely to perform poorly.

\section{Introduction}

Sorghum (Sorghum bicolor L. Moench) is an important and widely adapted small-grain cereal grown in the tropics and subtropics and a staple food grain in food-insecure regions of Asia, Africa, and Central America [1]. Sorghum ranks second in importance after maize in Africa with a mean yield of $0.8 \mathrm{t} /$ ha from a cultivated area of about 24 million hectares [2]. According to a review by Keya and Rubaihayo [3] sorghum ranks fifth after maize, cassava, rice, and wheat as staple in Tanzania. Nonetheless, sorghum plays a significant role in fighting hunger and food insecurity in central Tanzania.

Few long-term field experiments exist with sufficient detail in space and time to enable an understanding of variability in sorghum production due to dynamics in soil, nutrient, varieties, management, and weather processes and their interactions. Previous short-term field experiments at different locations and seasons, both on-farm and on-station, obtained higher grain yields, for instance, [4] $\left(2.65 \mathrm{tha}^{-1}\right)$ and [5] (2.58 $\left.\mathrm{tha}^{-1}\right)$ for var. Tegemeo, contrary to the results by Saadan et al. [6] which showed that vars. Pato and
Macia were superior to var. Tegemeo. Although short-term field experiments provide data with high degree of accuracy [7], they suffer from the failure to capture the interannual variability due to environmental conditions. Results from the previous experiments on improved sorghum varieties show that grain yields vary among varieties and across locations and seasons. Thus being short lived, the ensuing experiments do not permit derivation of robust conclusions about yield performance and adaptation of sorghum varieties over a long-term period.

Moreover, over the past years concerns have grown on increased rainfall variability across seasons resulting in large yield variability and thus becoming an apparent determinant on the performance and adaptation of sorghum varieties [8,9]. Thus studies are essential which would combine long-term period and multiple locations (spatialtemporal analysis) under variable rainfall and soils to elucidate sorghum varieties' performance. Moreover, alongside such studies, analyses of rainfall trends are deemed necessary to understand the vulnerability of semiarid regions to historical and projected future conditions. Some rainfall 
analyses have shown decreasing trends (e.g., [10]) associated with decreases in the number of rainy days, while others have revealed neither abrupt changes nor trends [11]. These contrasting results suggest the need for undertaking location specific analyses of rainfall trends to ascertain contentious assertions on the same. A combination of field experiments and computer simulation models could be an appropriate option to comprehend the biophysical (climatic and soil conditions) factors and their interactions affecting crop yield and productivity $[12,13]$.

The Agricultural Production System sIMulator (APSIM) [14] is able to simulate growth and yield under different management practices and has been used by several studies under semiarid environments (e.g., $[15,16])$. This study, therefore, used the APSIM model to simulate sorghum growth and yield patterns over the current (baseline) climate under existing soil conditions and local management practices across selected locations in semiarid central Tanzania. Specifically, the study used APSIM crop simulation model to investigate how rainfall variability may affect yields of improved sorghum varieties based on long-term historical rainfall and projected climate.

\section{Materials and Methods}

2.1. Study Area. The central zone comprising Dodoma and Singida regions is located between latitudes $6^{\circ}$ and $06^{\circ} 08 \mathrm{~S}$ and longitudes $34^{\circ} 30^{\prime}$ and $35^{\circ} 45^{\prime} \mathrm{E}$. The experimental site was located at Hombolo Agricultural Research Institute (ARI) in Dodoma Region about $58 \mathrm{~km}$ North-East of Dodoma Municipality at latitude $05^{\circ} 45^{\prime} \mathrm{S}$ and longitude $35^{\circ} 57^{\prime} \mathrm{E}$. The mean annual rainfall is $589 \mathrm{~mm}$ but the distribution is highly variable. The average annual temperature is $22.7^{\circ} \mathrm{C}$. Soils at the experimental site are mainly sandy and loamy of low fertility. They are classified as Ferralic Cambisols in the FAO classification [17].

2.2. Experimental Design and Data Collection. Field experiments were conducted during 2012/13 and 2013/14 seasons. Three sorghum varieties, namely, Tegemeo, Macia, and Pato (the most widely grown varieties in the central zone), were used as treatments in a randomized complete block design (RCBD) with three replications. The recommended agronomic practices such as plant spacing and weeding are similar for the three varieties. Sowing was conditioned upon the previous day having received significant rainfall so as to wet the soil. Sorghum was sown at a spacing of $0.75 \mathrm{~m}$ between rows and $0.30 \mathrm{~m}$ within the row resulting in a plant density of 12 plants $\mathrm{m}^{-2}$. Weeding was done manually three times during the season on each plot using a hand hoe.

In order to provide near-optimum conditions, diammonium phosphate (DAP) fertilizer was applied during planting to supply $25 \mathrm{~kg} \mathrm{P} / \mathrm{ha}$ and $40 \mathrm{~kg} \mathrm{~N} / \mathrm{ha}$. Another round of N fertilization was done by applying $40 \mathrm{~kg} \mathrm{~N} / \mathrm{ha}$ as Urea seven weeks after planting. The phenological data collected for the three sorghum varieties included date of flowering and date of physiological maturity. These were noted when 50\% of plant population in each plot had attained that respective stage. Grain maturity was regarded to have been reached when dark spots at the point of attachment of the grain to the panicle started to show which was towards the end of April for both seasons. At final harvest, total aboveground biomass and grain yield were determined.

2.3. Historical Climatic Trends. Daily weather data during both seasons were obtained from observations at an agromet station, located about $500 \mathrm{~m}$ from the experimental plots. Past climate data (1961-2010) for selected weather stations, except Hombolo (1974-2010) in the central zone Tanzania, were analysed for trends. INSTAT plus (v3.36) software [18] was used to summarize the daily data into annual, monthly, and seasonal totals and to determine the onset taken as the first occasion after the earliest possible date on which a running total of at least $20 \mathrm{~mm}$ of rain was reached in four consecutive days with at least two days being wet and that no dry spell of 10 days or more occurred in the next 30 days [19]. Cessation of the rainy season was obtained through a water balance method and verified by visual daily display in INSTAT and length of growing period (LGP) was taken as the duration between the onset and cessation dates.

The Mann-Kendall test was used to test for significance of time series trends in total annual rainfall, seasonal rainfall, onset date, cessation date, and LGP. The Mann-Kendall test is less sensitive to outliers and has the capability to detect both linear and nonlinear trends and has been used in related studies in sub-Saharan Africa [20,21]. The median measure was used to show onset and cessation dates and days of LGP as it is relatively unaffected by extreme values compared to the mean.

The Mann-Kendall test statistic is given as

$$
S=\sum_{i=1}^{N-1} \sum_{j=i+1}^{N} \operatorname{sgn}\left(x_{j}-x_{i}\right),
$$

where $S$ is the Mann-Kendall test statistic; $x_{i}$ and $x_{j}$ are the sequential data values of the time series in the years $i$ and $j(j>i)$, and $N$ is the length of the time series. A positive $S$ value indicates an increasing trend and a negative value indicates a decreasing trend in the data series. The sign function is given as

$$
\operatorname{sgn}\left(x_{j}-x_{i}\right)= \begin{cases}+1 & \text { if }\left(x_{j}-x_{i}\right)>0 \\ 0 & \text { if }\left(x_{j}-x_{i}\right)=0 \\ -1 & \text { if }\left(x_{j}-x_{i}\right)<0 .\end{cases}
$$

For $N$ larger than $10, Z_{\mathrm{MK}}$ approximates the standard normal distribution [22] and is computed as follows:

$$
Z_{\mathrm{MK}}= \begin{cases}\frac{S-1}{\sqrt{\operatorname{Var}(S)}} & \text { if } S>0 \\ 0 & \text { if } S=0 \\ \frac{S+1}{\sqrt{\operatorname{Var}(S)}} & \text { if } S<0\end{cases}
$$


The presence of a statistically significant trend is evaluated using the $Z_{\mathrm{MK}}$ value. In a two-sided test for trend, the null hypothesis $H_{0}$ should be accepted if $\left|Z_{\mathrm{MK}}\right|<Z_{1-\alpha / 2}$ at a given level of significance. $Z_{1-\alpha / 2}$ is the critical value of $Z_{\mathrm{MK}}$ from the standard normal table (e.g., for $5 \%$ significance level, the value of $Z_{1-\alpha / 2}$ is 1.96 ).

2.4. Model Description, Calibration, and Evaluation. The theory and parameterization of the APSIM model used in this study have been described in Ncube et al. [23]. APSIM has been tested in a diverse range of systems and environments, as well as model performance in long-term cropping systems in semiarid and subhumid environments in sub-Saharan Africa $[24,25]$. The sorghum module used in the present study simulates the growth of a sorghum crop on a daily time step (on an area basis and not a single plant). Sorghum growth in this module responds to climate (temperature, rainfall, and radiation from the met module), soil water supply (from the SoilWat module), and soil nitrogen (from the SoilN module). Crop development is controlled by temperature (thermal degree days) and photoperiod. Thermal time accumulations were derived using an algorithm described in Jones and Kiniry [26] using observed phenology and weather data, a base temperature of $8^{\circ} \mathrm{C}$, and an optimal temperature of $30^{\circ} \mathrm{C}$. Genetic coefficients used by APSIM for sorghum are expressed in thermal degrees and photoperiod. The factor controlling the effect of photoperiod was set to a minimum value of 0.01 to eliminate the effect of photoperiod from the varieties as "modern" varieties are photoperiod insensitive [27]. In the present study, the APSIM model was evaluated for simulation of days after sowing to flowering and maturity, dry matter accumulation (biological yield), and grain yield.

Soil water dynamics between soil layers were defined by the cascading water balance method [28]. Its characteristics in the model are specified by the drained upper limit (DUL), lower limit of plant extractable water (LL15), and saturated water content (SAT). Soil characteristics of a soil profile opened up at the experimental site including soil texture, $\mathrm{pH}$ of soil, organic carbon content, and cation exchange capacity are shown in Table 1. Characteristics for the additional soil profiles used in simulations at different locations across the study area were obtained from the available soil databases (Table 2).

Each APSIM module demands a number of parameters. For the SOILWAT module, which simulates the dynamics of soil water, the inputs included soil bulk density, LL15 and DUL, and two parameters, $U$ and CONA, which determine first- and second-stage soil evaporation. LL15 and DUL and SAT were estimated according to Saxton et al. [29]. The parameters, $U$ and CONA, were set at $6.0 \mathrm{~mm}$ day 1 and $3 \mathrm{~mm}$ day 1 , respectively, values acceptable for tropical conditions [30]. A value of 0.7 was used for SWCON, a coefficient that specifies the proportion of the water in excess of field capacity that drains to the next layer in one day [30]. The bare soil runoff curve number (cn2_bare) was set to 50 to account for the low runoff because of the flat topography and high infiltration rates due to the sandy soil nature of the experimental site ([31] cited by [32]). Parameters influencing soil fertility are mainly represented in APSIM-SoilN2 module. For the soil $\mathrm{N}$ model the organic carbon content for each soil layer was measured at the experimental site. The initial soil $\mathrm{N}$ was set at $25 \mathrm{~kg} / \mathrm{ha}\left(20 \mathrm{~kg} \mathrm{NO}{ }_{3}-\mathrm{N} / \mathrm{ha}\right.$ and $\left.5 \mathrm{~kg} \mathrm{NH}_{4}{ }^{+}-\mathrm{N} / \mathrm{ha}\right)$ for the top two layers based on published data around central Tanzania [33], and $P$ was assumed nonlimiting.

The calibrated model was evaluated by comparing observed values for grain yield and total aboveground biomass with those from model simulations. Model performance was assessed through root mean square error (RMSE) [34],

$$
\mathrm{RMSE}=\sqrt{\frac{1}{N}} \sum(\widehat{Y} i-Y i)^{2}
$$

and index of agreement or $d$-statistic [35],

$$
d=1-\left[\frac{\sum_{i=1}^{n}(\widehat{Y} i-Y i)(\widehat{Y} i-Y i)}{\sum_{i=1}^{n}(|\widehat{Y} i-\bar{Y} i|+|Y i-\bar{Y} i|)}\right],
$$

where $\widehat{Y}, Y$, and $\bar{Y}$ are, respectively, the simulated, observed, and mean of the observed values and $n$ is the number of observations. For good agreement between model simulations and observations, $d$-statistic should approach unity.

2.5. Future Climate Data for Sorghum Yield Projections. Future climate data were obtained from Coupled Model Intercomparison Project phase 5 (CMIP5) under three Global Circulation Models (GCMs), namely, GFDL-ESM2M, HadGEM2-ES, and MIROC5 for mid-century RCP8.5 using the method by Hempel et al. [36]. Subsequently, simulations were performed for the three sorghum varieties under current (1980-2010) climate and yields compared with those obtained under future climatic conditions. The RCP8.5 is a high emissions scenario, corresponding to projections of high human population (12 billion by 2100), high rates of urbanization, and limited rates of technological change, all resulting in emissions approaching $30 \mathrm{Gt}$ of carbon by 2100 compared with $8 \mathrm{Gt}$ in 2000 [37].

2.6. Statistical Analysis. Analysis of variance (ANOVA) was used to analyse yield and total biomass data from the different treatments, with variety and replication, used as fixed and random effects, respectively. Test of significance between the 2012/2013 and 2013/2014 experiments was done using a $t$ test for pairwise comparison of means. Analysis of variance was performed using GENSTAT (v. 14) software (VSN international Ltd., Hempstead, England) whereas paired $t$ test was performed using Microsoft Excels' add-in Analyseit (Analyse-it Software Ltd., The Tannery, 91 Kirkstall Road Leeds, LS31HS, United Kingdom).

\section{Results and Discussion}

3.1. Trends in Onset and Cessation Dates and Length of Growing Period. The median for onset of rainfall begins on the last week of November to first week of December (Table 3). Standard deviation varied between 11 and 15 days. 
TABLE 1: Soil physical and chemical properties used for the calibration of APSIM.

\begin{tabular}{|c|c|c|c|c|c|c|}
\hline \multirow{2}{*}{ Soil parameters } & \multicolumn{6}{|c|}{ Layers } \\
\hline & $150 \mathrm{~mm}^{\mathrm{a}}$ & $150 \mathrm{~mm}^{\mathrm{a}}$ & $150 \mathrm{~mm}^{\mathrm{a}}$ & $250 \mathrm{~mm}^{\mathrm{a}}$ & $350 \mathrm{~mm}^{\mathrm{a}}$ & $300 \mathrm{~mm}^{\mathrm{a}}$ \\
\hline $\mathrm{BD}\left(\mathrm{g} \mathrm{cm}^{-3}\right)$ & 1.38 & 1.47 & 1.44 & 1.38 & 1.51 & 1.51 \\
\hline $\operatorname{SAT}\left(\mathrm{cm} \mathrm{cm}^{-1}\right)$ & 0.37 & 0.35 & 0.34 & 0.33 & 0.33 & 0.33 \\
\hline $\operatorname{LL}\left(\mathrm{cm} \mathrm{cm}^{-1}\right)$ & 0.084 & 0.084 & 0.134 & 0.134 & 0.134 & 0.14 \\
\hline $\operatorname{DUL}\left(\mathrm{cm} \mathrm{cm}^{-1}\right)$ & 0.248 & 0.299 & 0.334 & 0.278 & 0.270 & 0.270 \\
\hline Clay (\%) & 19 & 20 & 23 & 25 & 34 & 30 \\
\hline Silt (\%) & 5 & 4 & 4 & 5 & 2 & 4 \\
\hline CEC (cmol/kg) & 6.0 & 8.2 & 9.2 & 10.2 & 10.0 & 6.0 \\
\hline \multicolumn{7}{|l|}{ Soil C parameters } \\
\hline Organic C (g $\left.100 \mathrm{~g}^{-1}\right)$ & 0.41 & 0.31 & 0.23 & 0.14 & 0.14 & 0.06 \\
\hline Finert $^{\mathrm{b}}$ & 0.4 & 0.6 & 0.8 & 0.8 & 0.9 & 0.9 \\
\hline Fbiom $^{c}$ & 0.025 & 0.02 & 0.015 & 0.01 & 0.01 & 0.01 \\
\hline
\end{tabular}

BD: bulk density; SAT: volumetric water content at saturation. LL is wilting point (volumetric water content at -15 bar pressure potential) and DUL is drained upper limit.

${ }^{a}$ Layer thickness $(\mathrm{mm})$.

${ }^{\mathrm{b}}$ Proportion of soil carbon assumed not to decompose.

${ }^{c}$ Proportion of decomposable soil carbon in the more labile soil organic matter pool.

TABLE 2: Soil properties of the profiles used in simulations across stations.

\begin{tabular}{|c|c|c|c|c|c|}
\hline Properties & Dodoma & Hombolo & Mpwapwa & Manyoni & Singida \\
\hline $\begin{array}{l}\text { Soil layers/depth } \\
(\mathrm{cm})\end{array}$ & $6 / 135$ & $6 / 135$ & $4 / 110$ & $4 / 115$ & $4 / 110$ \\
\hline $\begin{array}{l}\text { Sand, silt, clay (\% } \\
\text { in } 0-15 \mathrm{~cm})\end{array}$ & $79,5,16$ & $79,5,16$ & $81,6,13$ & $66,10,14$ & $55,21,24$ \\
\hline Textural class & Sandy loam & Sandy loam & Sandy loam & Sandy loam & $\begin{array}{c}\text { Sandy clay } \\
\text { loam }\end{array}$ \\
\hline $\begin{array}{l}\text { Plant available } \\
\text { water }\end{array}$ & 119.2 & 119.2 & 112.8 & 164.1 & 162.1 \\
\hline $\begin{array}{l}\text { Organic carbon } \\
\text { (top three layers) }\end{array}$ & $\begin{array}{c}0.32,0.21 \\
0.11 \\
\end{array}$ & $\begin{array}{c}0.32,0.21 \\
0.11\end{array}$ & $\begin{array}{l}0.45,0.30 \\
0.15\end{array}$ & $\begin{array}{l}0.56,0.32 \\
\quad 0.12\end{array}$ & $\begin{array}{c}0.52,0.38 \\
\quad 0.20\end{array}$ \\
\hline
\end{tabular}

TABLE 3: Statistical characteristics and trends of onset date, cessation date, and LGP at five stations over the period 1961-2010 in central Tanzania.

\begin{tabular}{|c|c|c|c|c|c|c|}
\hline Station & Statistics & Dodoma & Mpwapwa & Hombolo & Manyoni & Singida \\
\hline \multirow{4}{*}{ Onset } & Median & Dec 13 & $\operatorname{Dec} 7$ & $\operatorname{Dec} 7$ & Dec 1 & Nov 26 \\
\hline & $Z_{\mathrm{MK}}$ & $-0.07^{\mathrm{ns}}$ & $-0.030^{\mathrm{ns}}$ & $-1.196^{*}$ & $-0.911^{\mathrm{ns}}$ & $-0.680^{\mathrm{ns}}$ \\
\hline & Slope & 0.00 & -0.091 & -0.321 & -0.225 & -0.131 \\
\hline & SD & 11.311 & 14.252 & 14.870 & 14.361 & 14.582 \\
\hline \multirow{4}{*}{ Cessation } & Median & Apr 18 & Apr 13 & Apr 5 & Apr 14 & Apr 30 \\
\hline & $Z_{\mathrm{MK}}$ & $-0.337^{\mathrm{ns}}$ & $-1.188^{\mathrm{ns}}$ & $0.970^{\mathrm{ns}}$ & $-0.755^{\mathrm{ns}}$ & $1.692^{*}$ \\
\hline & Slope & 0.000 & -0.083 & 0.029 & -0.070 & 0.303 \\
\hline & SD & 10.252 & 16.041 & 11.054 & 14.281 & 16.711 \\
\hline \multirow{4}{*}{ LGP (days) } & Median & 124 & 122 & 123 & 141 & 145 \\
\hline & $Z_{\mathrm{MK}}$ & $-0.303^{\mathrm{ns}}$ & $-0.419^{\mathrm{ns}}$ & $2.092^{*}$ & $-0.480^{\mathrm{ns}}$ & $1.876^{*}$ \\
\hline & Slope & 0.000 & -0.067 & 0.434 & 0.000 & 0.692 \\
\hline & CV (\%) & 12.510 & 13.711 & 14.281 & 13.511 & 15.982 \\
\hline
\end{tabular}

$Z_{\mathrm{MK}}$ is Mann-Kendall trend test, slope (Sen's slope) is the change (days)/annum; * is statistically significant at 0.05 probability level; ns is nonsignificant trend; $\mathrm{SD}$ is standard deviation; $\mathrm{CV}$ is coefficient of variation. 
The results indicated that the onset dates in the last 50 years have changed with all stations depicting early trends. However, the trends are not statistically significant except for Hombolo station. According to the analysed data, cessation of rainfall starts from the first week of April (at Hombolo) to last week of April (at Singida) (Table 3). Munishi [38] also reported similar findings in central Tanzania with slightly earlier onset and cessation dates. The median date for rainfall cessation was characterized by high standard deviation $(>10$ days) at all stations implying high variability in the pattern of end of the rainy season. However, these results are contrary to other studies which have shown less variable cessation dates than onset dates $[19,39]$.

Median LGP in the central Tanzania varied from 122 to 145 days depending on the location of the station (Table 3). All stations had higher coefficients of variation $(>13 \%)$ in LGP which indicate high year to year variability of LGP except for Dodoma (12\%). Higher coefficients of variation $(>13 \%)$ in LGP give less confidence in crop selection based on maturity period. From the analyses, a mix of increasing and decreasing trends in LGP was obtained. Singida and Hombolo stations show statistically significant increasing trends in LGP (Table 3). However, Dodoma, Mpwapwa, and Manyoni stations had nonsignificant decreasing trends in LGP, results which are in agreement with findings from earlier studies which indicate that LGP has been shortening with a decreasing trend of number of rainy days during the growing season $[19,38,40]$.

3.2. Climate Change Projections. Selected GCMs consistently projected increased temperatures for selected weather stations in the central zone of Tanzania. Projected temperature changes showed a mean increase in the range of $1.4-2.8^{\circ} \mathrm{C}$ (Table 4). In contrast, the projected change in rainfall across the stations showed decline, except for MIROC5, which showed an increase of $+4.5-7.3 \%$ (Table 5 ). While projected rainfall changes were variable and uncertain, the projected temperature changes showed strong consistency with an upward trend.

3.3. Field Experimental Results. Table 5 shows grain yields and aboveground biomass obtained during the two experimental seasons.

There was no significant variation among varieties in the $2012 / 2013$ season with respect to biomass at 50\% anthesis, biomass at harvest maturity, and grain yield (Table 6). However, during the season of 2013/2014, significant variation $(P<0.05)$ in the three variables was observed among varieties. Further, there was interseasonal variation in plant biomass at $50 \%$ anthesis, grain yield,and biomass at harvest as indicated by the $t$-statistic in Table 6 .

3.4. Model Calibration and Evaluation. Genetic coefficients used by APSIM for sorghum after calibration are shown in Table 7.

Comparison between observed and simulated grain and biomass yield combined for the two seasons is shown in Table 8. Statistical indicators show the simulation efficiency of APSIM model in simulating sorghum. Root mean square error (RMSE) which is an overall measure of model performance and compares simulated versus observed values shows a good agreement because the lower the values of RMSE the better the model in explaining most of the variations in the dataset. Moreover, data indicate that the simulated grain and biomass yield values reasonably matched observed values, owing to the agreement index ( $d$-statistic) ranging from 0.6 to 0.9 across the varieties. The $d$-statistic values close to 1 are regarded as better simulations and according to these statistical indicators the model performance was deemed satisfactory to allow continuation of simulations both for long-term (temporal) and at different locations (spatial).

3.5. Influence of Water Stress on Sorghum Grain Yield. Simulated grain yields for the three varieties at the experimental station are shown in Figure 1. The simulation package consisted of planting between 15 December and 15 January, a row spacing of $0.90 \mathrm{~m}$, and a population of 9 plants per $\mathrm{m}^{2}$ without $\mathrm{N}$ fertilizer under baseline weather (1980-2010). Results indicated that simulated yields varied among varieties with the range of $2.65-2.88 \mathrm{tha}^{-1}$ for the highest yields, and $0.48-0.57 \mathrm{tha}^{-1}$ for the lowest yields.

Further examination of rainfall and yields in 1998 (the year producing the lowest simulated yields) and 2008 (the year producing the highest simulated yields) demonstrates the importance of rainfall distribution during the growing period and especially during critical stages. There was approximately $0.50 \mathrm{tha}^{-1}$ maize yield in 1998 compared to $2.80 \mathrm{tha}^{-1}$ in 2008 (Figure 1). This was probably due to water stress. It means that yields simulated by APSIM are highly sensitive to wet/dry spell sequences during the crop growing season. Baigorria et al. [41] observe that not only is increasing persistence of wet/dry day occurrences important, but also the timing within the growing season is important when these wet/dry spells occurred. Decadal analyses of rainfall for occurrences of 5- and 10-day dry spells shown in Table 9 indicate that in 1998 the occurrence of a 10-day dry spell during the first decade in March caused strong water stresses which significantly reduced sorghum grain yields. On the contrary sorghum experienced only a brief water stress period (5-day dry spell during the same period); as a result much higher yields were obtained in 2008. According to the sowing dates in the simulation package, the period represents the crop growth stages from flag leaf appearance to start of grain filling. Premachandra et al. [42] indicate that as the most sensitive period for sorghum response to drought among phenological phases.

3.6. Simulations under Both the Baseline and Future Climates. Mean simulated sorghum yields obtained from different locations (weather stations) across the central zone of Tanzania are shown in Figure 2. Taking into account uniform farmers' management practices across the study area, the simulated sorghum yields were envisaged to be influenced by the response to rainfall and soil variability. However, despite the differences in rainfall projections shown by the GCMs 
TABLE 4: Mean change in projected climate between baseline (1980-2010) and mid-century (2040-2069) RCP8.5.

\begin{tabular}{|c|c|c|c|c|c|}
\hline \multirow{2}{*}{ Station } & \multirow{2}{*}{ GCM } & \multicolumn{3}{|c|}{ Temperature $\left({ }^{\circ} \mathrm{C}\right)$} & \multirow{2}{*}{ Rainfall (\%) } \\
\hline & & Average & Minimum & Maximum & \\
\hline \multirow{3}{*}{ Dodoma } & GFDL-ESM2M & 1.4 & 1.7 & 1.2 & -8.5 \\
\hline & HADGEM2-ES & 2.8 & 2.9 & 2.8 & -1.4 \\
\hline & MIROC5 & 2.2 & 2.1 & 2.4 & 7.3 \\
\hline \multirow{3}{*}{ Manyoni } & GFDL-ESM2M & 1.8 & 1.8 & 1.7 & -3.0 \\
\hline & HADGEM2-ES & 2.7 & 2.6 & 2.8 & -5.2 \\
\hline & MIROC5 & 2.3 & 2.1 & 2.4 & 7.0 \\
\hline \multirow{3}{*}{ Singida } & GFDL-ESM2M & 1.8 & 1.8 & 1.7 & -1.9 \\
\hline & HADGEM2-ES & 2.7 & 2.6 & 2.8 & -2.7 \\
\hline & MIROC5 & 2.3 & 2.1 & 2.4 & 4.5 \\
\hline
\end{tabular}

TABLE 5: Grain yield, aboveground biomass, and harvest index for seasons 2012/13 and 2013/14.

\begin{tabular}{|c|c|c|c|c|c|c|c|}
\hline \multirow[b]{2}{*}{ Variety } & \multicolumn{2}{|c|}{$2012 / 13$} & \multicolumn{2}{|c|}{$2013 / 14$} & \multicolumn{3}{|c|}{ Combined seasons } \\
\hline & $\begin{array}{l}\text { Grain yield } \\
(\mathrm{kg} / \mathrm{ha})\end{array}$ & $\begin{array}{c}\text { Aboveground } \\
\text { biomass } \\
(\mathrm{kg} / \mathrm{ha})\end{array}$ & $\begin{array}{l}\text { Grain yield } \\
\text { (kg/ha) }\end{array}$ & $\begin{array}{c}\text { Aboveground } \\
\text { biomass } \\
(\mathrm{kg} / \mathrm{ha})\end{array}$ & $\begin{array}{c}\text { Days to } 50 \% \\
\text { flowering }\end{array}$ & $\begin{array}{l}\text { Days to } \\
\text { harvest } \\
\text { maturity }\end{array}$ & $\begin{array}{c}\text { Plant height } \\
\text { (max) } \\
\mathrm{mm}\end{array}$ \\
\hline Macia & $4064^{*}$ & 10517 & 4355 & 11388 & 65 & 102 & 1290 \\
\hline Pato & 3896 & 11411 & 4088 & 12394 & 76 & 118 & 1780 \\
\hline Tegemeo & 3798 & 10843 & 4012 & 11415 & 74 & 114 & 1650 \\
\hline S.E.D & 233.9 & 274.3 & 79.1 & 100.7 & 0.577 & 0.471 & 147.1 \\
\hline
\end{tabular}

${ }^{*}$ Means over three replications. S.E.D $=$ standard error of differences of means.

TABLE 6: Intra- and interseasonal variation in biomass, grain yield, and tops weight.

\begin{tabular}{lccc}
\hline Variable & $2012 / 2013$ & $2013 / 2014$ & $t$-statistic \\
\hline Biomass at $50 \%$ anthesis & $2.77^{\mathrm{ns}}$ & $5.49^{*}$ & $3.89^{* *}$ \\
Grain yield at harvest & $1.41^{\mathrm{ns}}$ & $21.08^{*}$ & $5.08^{*}$ \\
Biomass at harvest maturity & $3.23^{\mathrm{ns}}$ & $50.49^{*}$ & $8.60^{*}$ \\
\hline
\end{tabular}

${ }^{*}$ Significant at $P<0.05 ;{ }^{* *}$ significant at $P<0.01 ; \mathrm{ns}=$ not significant.

TABLE 7: Crop parameters for three sorghum cultivars used for the simulations in APSIM.

\begin{tabular}{|c|c|c|c|c|c|c|}
\hline Parameter & & Source & Units & Macia & Tegemeo & Pato \\
\hline \multirow{5}{*}{ Thermal time accumulation } & End of juvenile phase to panicle initiation & $\mathrm{C}$ & ${ }^{\circ} \mathrm{C}$ day & 230 & 270 & 275 \\
\hline & Flag stage to flowering & $\mathrm{C}$ & ${ }^{\circ} \mathrm{C}$ day & 195 & 170 & 175 \\
\hline & Flowering to start of grain filling & $\mathrm{C}$ & ${ }^{\circ} \mathrm{C}$ day & 80 & 80 & 100 \\
\hline & Flowering to maturity & $\mathrm{C}$ & ${ }^{\circ} \mathrm{C}$ day & 675 & 760 & 760 \\
\hline & Maturity to seed ripening & $\mathrm{L}$ & ${ }^{\circ} \mathrm{C}$ day & 1 & 1 & 1 \\
\hline \multirow{6}{*}{ Photoperiod } & Day length photoperiod to inhibit flowering & $\mathrm{D}$ & $\mathrm{H}$ & 11.5 & 11.5 & 11.5 \\
\hline & Day length photoperiod for insensitivity & $\mathrm{D}$ & $\mathrm{H}$ & 13.5 & 13.5 & 13.5 \\
\hline & Photoperiod slope & $\mathrm{L}$ & ${ }^{\circ} \mathrm{C} / \mathrm{h}$ & 0.01 & 0.01 & 0.01 \\
\hline & Base temperature & $\mathrm{L}$ & ${ }^{\circ} \mathrm{C}$ day & 8 & 8 & 8 \\
\hline & Optimum temperature & $\mathrm{D}$ & ${ }^{\circ} \mathrm{C}$ day & 30 & 30 & 30 \\
\hline & Plant height (max) & $\mathrm{O}$ & $\mathrm{mm}$ & 1290 & 1650 & 1780 \\
\hline
\end{tabular}

C: calibrated; D: default; L: literature; O: observed.

TABLE 8: Statistical indicators of model performance.

\begin{tabular}{lcccccc}
\hline \multirow{2}{*}{ Parameters/cultivar } & \multicolumn{2}{c}{ Macia } & \multicolumn{2}{c}{ Tegemeo } & \multicolumn{2}{c}{ Pato } \\
& RMSE (kg/ha) & $d$-Stat & RMSE (kg/ha) & $d$-Stat & 0.62 & 140 \\
Grain yield & 133 & 0.73 & 87 & 418 & 0.66 & 0.60 \\
Biomass & 178 & 0.93 & RSE $(\mathrm{kg} / \mathrm{ha})$ & 236 \\
\hline
\end{tabular}


TABLE 9: Occurrences of dry spells during March and April and their relationship to simulated grain yields at Hombolo.

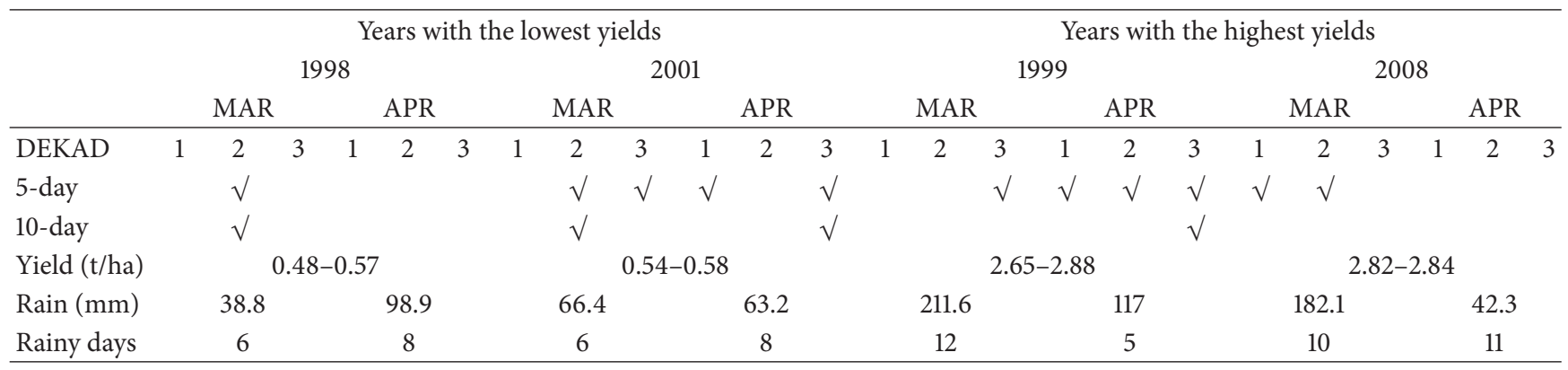

$\sqrt{ }$ indicates occurrence of a dry spell in a decade (10-day interval) within a month.

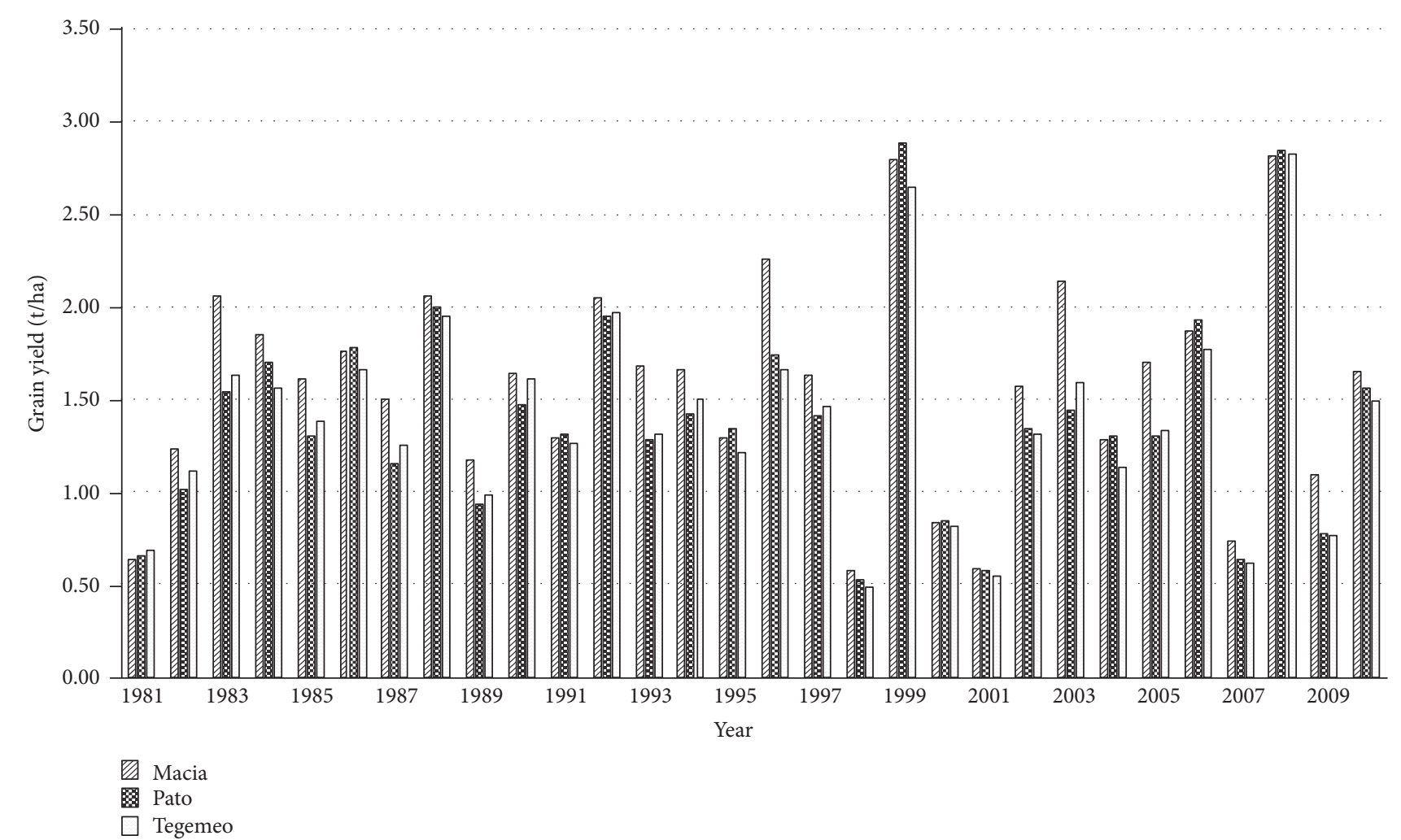

FIGURE 1: Simulated grain yield of sorghum varieties under baseline (1980-2010) conditions at Hombolo.

(Table 6), the simulated average sorghum yields were consistently higher under all GCMs (with HADGEM-ES giving the highest) compared with baseline for all the three sorghum varieties. The increased yield, therefore, may be attributed to temperature increases. Similarly, Turner and Rao and Zinyengere et al. [43, 44] find sorghum gaining in terms of grain yields from higher temperatures in specific regions with lower baseline temperatures (below $20^{\circ} \mathrm{C}$ ). Simulation results from the current study could answer the questions about future development trajectory in the study area. Moreover, as discussed by Enfors et al. [45], increasing investments in small-scale water system technologies provides opportunities for the small-scale farming systems that dominate the study area to leverage the uncertainty of the future climates.

\section{Conclusions}

The field experimental results for the two seasons show considerable variations in grain yields among varieties. An early maturing variety Macia gave higher yields in both seasons compared to vars. Pato and Tegemeo. Model simulated yields reveal that the length and timing of dry spells during the growing season are major determinants of grain yields and they surpass total seasonal rainfall amount even for a hardy 


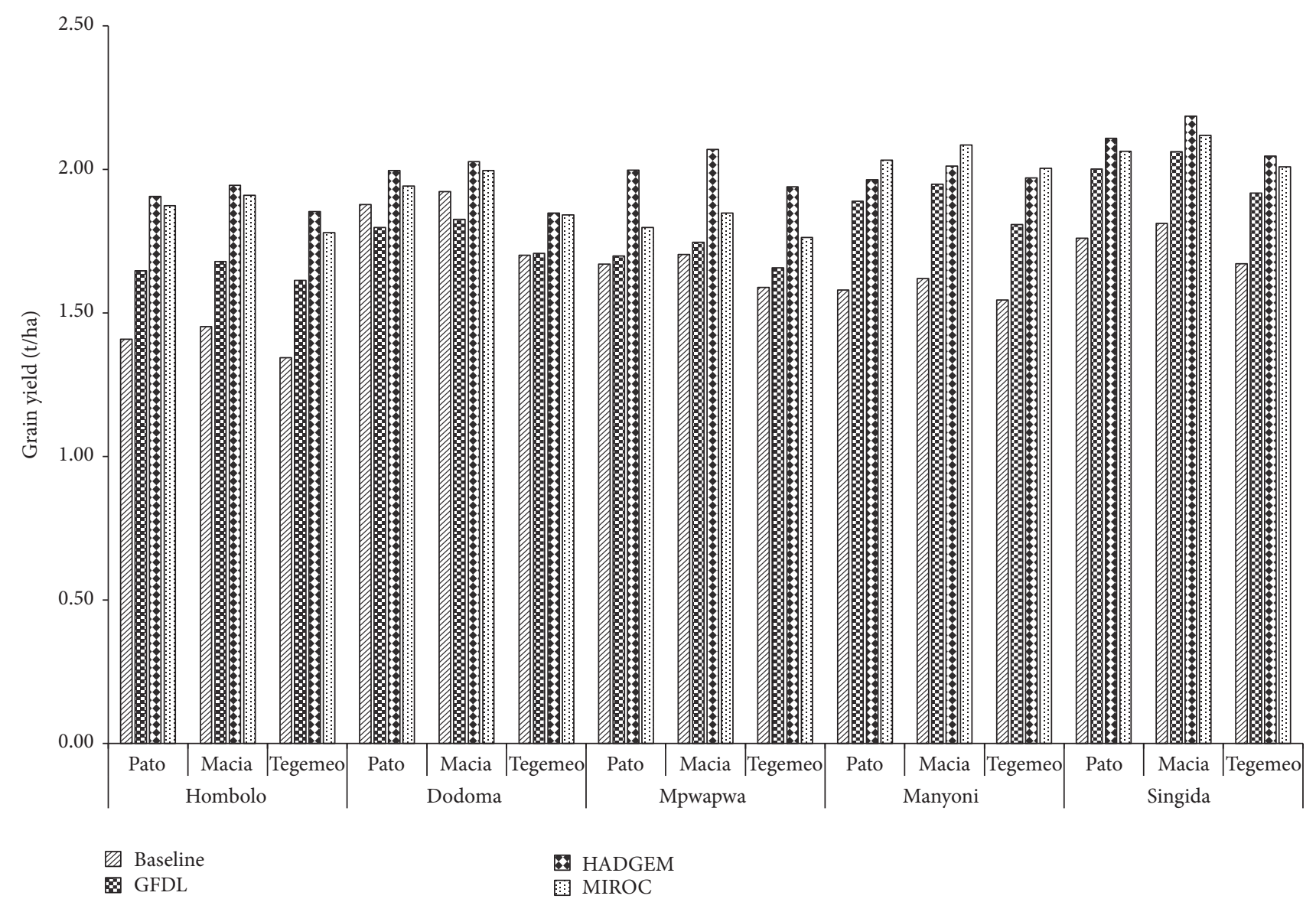

FIGURE 2: Simulated grain yields of Pato, Macia, and Tegemeo sorghum varieties under baseline and future climatic conditions in central Tanzania.

crop like sorghum. Results suggest that occurrence of a long dry spell (10-day or longer) during the period from flag leaf appearance to start of grain filling is critical and could significantly reduce yield. Therefore, considering the inability of smallholder farmers to construct and maintain rain-water harvesting (RWH) structures, the government and development partners should consider increasing investments in the same to ensure supplemental irrigation during critical stages. The availability of water would enable smallholders growing sorghum to leverage the uncertainty in climate, but also to tap the opportunities brought in by increased temperatures. The phenological characterization of the three varieties and subsequent calibration and validation of APSIM have provided a basis on which various kinds of simulations could be done with the aim of increasing and sustaining sorghum productivity.

\section{Disclosure}

This paper is based on the first chapter of a Ph.D. dissertation submitted to Sokoine University of Agriculture (SUA). Any errors in the article are the authors' responsibility.

\section{Conflicts of Interest}

The authors declare that there are no conflicts of interest regarding the publication of this paper.

\section{Acknowledgments}

The authors thank the project "Enhancing Climate Change Adaptation in Agriculture and Water Resources in the Greater Horn of Africa (ECAW)" under the Soil Water Management Research Group (SWMRG) of Sokoine University of Agriculture for partially supporting this research.

\section{References}

[1] P. Q. Craufurd, V. Mahalakshmi, F. R. Bidinger et al., "Adaptation of sorghum: characterisation of genotypic flowering responses to temperature and photoperiod," Theoretical and Applied Genetics, vol. 99, no. 5, pp. 900-911, 1999.

[2] M. K. Maredia, D. Byerlee, and P. Pee, "Impacts of food crop improvement research: evidence from sub-Saharan Africa," Food Policy, vol. 25, no. 5, pp. 531-559, 2000. 
[3] S. Keya and P. Rubaihayo, "Progress in on-farm production and productivity in the east african community: 50 years after independence," Kilimo Trust Technical Paper No. 8, International Symposium on Agriculture: EAC partner states at 50 years, November, 2013.

[4] N. Hatibu, H. F. Mahoo, E. M. Senkondo et al., "Strategies for soil-water management for dryland crop production in semiarid Tanzania," in Proceedings of Tanzania Society of Agricultural Engineers, vol. 6, pp. 83-97, 1993.

[5] T. L. Bucheyeki, E. M. Shenkalwa, T. X. Mapunda, and L. W. Matata, "Yield performance and adaptation of four sorghum cultivars in Igunga and Nzega districts of Tanzania," Communications in biometry and crop science, vol. 5, no. 1, pp. 4-10, 2010.

[6] H. M. Saadan, M. A. Mgonja, and A. B. Obilana, Performance of the Sorghum Variety Macia in Multiple Environments in Tanzania, 2000.

[7] J. Mugwe, D. Mugendi, J. Kungu, and M.-M. Muna, "Maize yields response to application of organic and inorganic input under on-station and on-farm experiments in central Kenya," Experimental Agriculture, vol. 45, no. 1, pp. 47-59, 2009.

[8] L. R. Stone and A. J. Schlegel, "Yield-water supply relationships of grain sorghum and winter wheat," Agronomy Journal, vol. 98, no. 5, pp. 1359-1366, 2006.

[9] K. Traore, J. B. Auneb, and B. Traore, "Effect of organic manure to improve sorghum productivity in flood recession farming in Yelimane, Western Mali," American Scientific Research Journal for Engineering, Technology, and Sciences, vol. 23, no. 1, pp. 232251, 2016.

[10] N. Batisani and B. Yarnal, "Rainfall variability and trends in semi-arid Botswana: implications for climate change adaptation policy," Applied Geography, vol. 30, no. 4, pp. 483-489, 2010.

[11] R. Lázaro, F. S. Rodrigo, L. Gutiérrez, F. Domingo, and J. Puigdefábregas, "Analysis of a 30-year rainfall record (1967-1997) in semi-arid SE spain for implications on vegetation," Journal of Arid Environments, vol. 48, no. 3, pp. 373-395, 2001.

[12] R. Matthews, W. Stephens, T. Hess, T. Middleton, and A. Graves, "Applications of crop/soil simulation models in tropical agricultural systems," Advances in agronomy, vol. 76, pp. 31-124, 2002.

[13] B. M. Msongaleli, Assessment of the impacts of climate variability and change on rainfed cereal crop productivity in central Tanzania [Ph.D. dissertation], Sokoine University of Agriculture, Morogoro, Tanzania, 2015.

[14] B. A. Keating, P. S. Carberry, G. L. Hammer et al., "An overview of APSIM, a model designed for farming systems simulation," European Journal of Agronomy, vol. 18, no. 3-4, pp. 267-288, 2003.

[15] D. S. MacCarthy and P. L. G. Vlek, "Impact of climate change on sorghum production under different nutrient and crop residue management in semi-arid region of Ghana: a modelling perspective," African Crop Science Journal, vol. 20, pp. 243-259, 2012.

[16] W. Mupangwa, J. Dimes, S. Walker, and S. Twomlow, "Measuring and simulating maize (Zea mays L.) yield responses to reduced tillage and mulching under semi-arid conditions," Agricultural Sciences, vol. 2, no. 3, pp. 167-174, 2011.

[17] A. C. Guzha, "Effects of tillage on soil microrelief, surface depression storage and soil water storage," Soil and Tillage Research, vol. 76, no. 2, pp. 105-114, 2004.

[18] R. Stern, D. Rijks, I. Dale, and J. Knock, INSTAT (Interactive Statistics) Climate Guide, 2006.
[19] N. I. Kihupi, A. K. P. R. Tarimo, and H. O. Dihenga, "Spatial and temporal variation of growing season characteristics in Tanzania," Journal of the Geographical Association of Tanzania, vol. 32, pp. 33-49, 2007.

[20] D. Mazvimavi, "Investigating changes over time of annual rainfall in Zimbabwe," Hydrology and Earth System Sciences, vol. 14, no. 12, pp. 2671-2679, 2010.

[21] G. Hadgu, K. Tesfaye, G. Mamo, and B. Kassa, “Trend and variability of rainfall in Tigray, Northern Ethiopia: analysis of meteorological data and farmers' perception," Academia Journal of Agricultural Research, vol. 1, pp. 88-100, 2013.

[22] K. Yenigun, V. Gumus, and H. Bulut, "Trends in streamflow of the Euphrates basin, Turkey," Proceedings of the Institution of Civil Engineers: Water Management, vol. 161, no. 4, pp. 189-198, 2008.

[23] B. Ncube, J. P. Dimes, M. T. van Wijk, S. J. Twomlow, and K. E. Giller, "Productivity and residual benefits of grain legumes to sorghum under semi-arid conditions in south-western Zimbabwe: unravelling the effects of water and nitrogen using a simulation model," Field Crops Research, vol. 110, no. 2, pp. 173184, 2009.

[24] A. M. Whitbread, M. J. Robertson, P. S. Carberry, and J. P. Dimes, "How farming systems simulation can aid the development of more sustainable smallholder farming systems in southern Africa," European Journal of Agronomy, vol. 32, no. 1, pp. 51-58, 2010.

[25] Z. J. Mkoga, S. D. Tumbo, N. Kihupi, and J. Semoka, "Extrapolating effects of conservation tillage on yield, soil moisture and dry spell mitigation using simulation modelling," Physics and Chemistry of the Earth, Parts A/B/C, vol. 35, no. 13-14, pp. 686698, 2010.

[26] C. A. Jones and J. Kiniry, CERES-Maize: A Simulation Model of Maize Growth and Development, Texas A \& M University Press, College station, TX, USA, 1986.

[27] M. Kouressy, M. Dingkuhn, M. Vaksmann, and A. B. Heinemann, "Adaptation to diverse semi-arid environments of sorghum genotypes having different plant type and sensitivity to photoperiod," Agricultural and Forest Meteorology, vol. 148, no. 3, pp. 357-371, 2008.

[28] J. T. Ritchie, "Soil water balance and plant water stress," in Understanding Options for Agricultural Production, Y. Tsuji, Y. Gordon, Gerrit Hoogenboom, and Philip. K. Thornton, Eds., pp. 45-58, Kluwer Academic, Dodrecht, The Netherlands, 1998.

[29] K. E. Saxton, W. J. Rawls, J. S. Romberger, and R. I. Papendick, "Estimating generalized soil-water characteristics from texture," Soil Science Society of America Journal, vol. 50, no. 4, pp. 10311036, 1986.

[30] R. Chikowo, Climatic Risk Analysis in Conservation Agriculture in Varied Biophysical and Socio-Economic Settings of Southern Africa, Food and Agriculture Organization of the United Nations (FAO), Rome, Italy, 2011.

[31] J. Hussein, "A review of methods for determining available water capacities of soils and description of an improved method for estimating field capacity," Zimbabwe Journal of Agricultural Research, vol. 21, pp. 73-87, 1983.

[32] J. Rurinda, P. Mapfumo, M. T. van Wijk et al., "Comparative assessment of maize, finger millet and sorghum for household food security in the face of increasing climatic risk," European Journal of Agronomy, vol. 55, pp. 29-41, 2014. 
[33] S. Pierce, A. M. Mbwaga, G. Ley et al., Chemical Characteristics of Soil And Sorghum from Striga-Infested Regions of Tanzania, and The Influence of Fertiliser Application, University of Sheffield, Sheffield, UK, 2003.

[34] D. Wallach, "Evaluating crop models," in Working with Dynamic Crop Models Evaluation, Analysis, Parameterization, and Applications, D. Wallach, D. Makowski, and J. W. Jones, Eds., pp. 1154, Elsevier, Amsterdam, The Netherlands, 2006.

[35] C. J. Willmott, S. G. Ackleson, R. E. Davis et al., "Statistics for the evaluation and comparison of models," Journal of Geophysical Research, vol. 90, pp. 8995-9005, 1985.

[36] S. Hempel, K. Frieler, L. Warszawski, J. Schewe, and F. Piontek, "A trend-preserving bias correction-the ISI-MIP approach," Earth System Dynamics, vol. 4, no. 2, pp. 219-236, 2013.

[37] K. Riahi, A. Grübler, and N. Nakicenovic, "Scenarios of longterm socio-economic and environmental development under climate stabilization," Technological Forecasting and Social Change, vol. 74, no. 7, pp. 887-935, 2007.

[38] P. K. T. Munishi, "Analysis of climate change and its impacts on productive sectors, particularly agriculture in Tanzania," Tech. Rep., Ministry of Finance and Economic Affairs, 2009.

[39] P. Camberlin and R. E. Okoola, "The onset and cessation of the 'long rains' in Eastern Africa and their interannual variability," Theoretical Applied Climatology, vol. 75, pp. 43-54, 2003.

[40] M. A. Lema and A. E. Majule, "Impacts of climate change, variability and adaptation strategies on agriculture in semiarid areas of Tanzania: the case of Manyoni District in Singida Region, Tanzania," African Journal of Environmental Science and Technology, vol. 3, no. 8, pp. 206-218, 2009.

[41] G. A. Baigorria, J. W. Jones, D. W. Shin, A. Mishra, and J. J. O'Brien, "Assessing uncertainties in crop model simulations using daily bias-corrected regional circulation model outputs," Climate Research, vol. 34, pp. 211-222, 2007.

[42] G. S. Premachandra, D. T. Hahn, and R. J. Joly, "Leaf water relations and gas exchange in two grain sorghum genotypes differing in their pre- and post-flowering drought tolerance," Journal of Plant Physiology, vol. 143, no. 1, pp. 96-101, 1994.

[43] N. C. Turner and K. P. C. Rao, "Simulation analysis of factors affecting sorghum yield at selected sites in eastern and southern Africa, with emphasis on increasing temperatures," Agricultural Systems, vol. 121, pp. 53-62, 2013.

[44] N. Zinyengere, O. Crespo, S. Hachigonta, and M. Tadross, "Local impacts of climate change and agronomic practices on dry land crops in Southern Africa," Agriculture, Ecosystems and Environment, vol. 197, pp. 1-10, 2014.

[45] E. I. Enfors, L. J. Gordon, G. D. Peterson, and D. Bossio, "Making investments in dryland development work: participatory scenario planning in the Makanya catchment, Tanzania," Ecology and Society, vol. 13, no. 2, p. 42, 2008. 


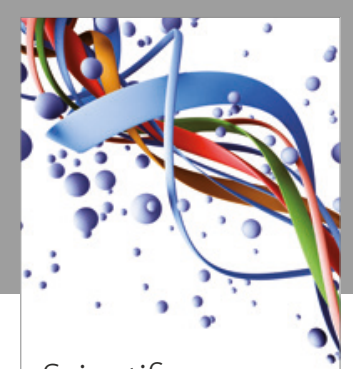

Scientifica
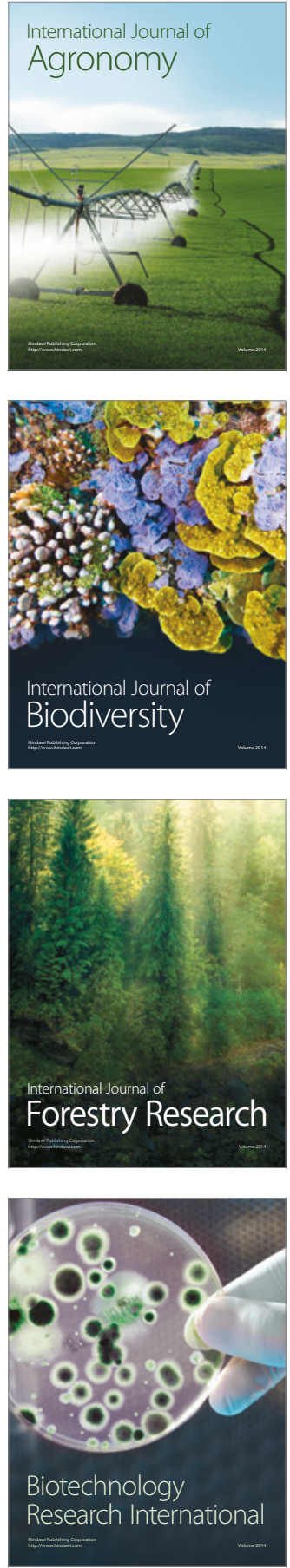
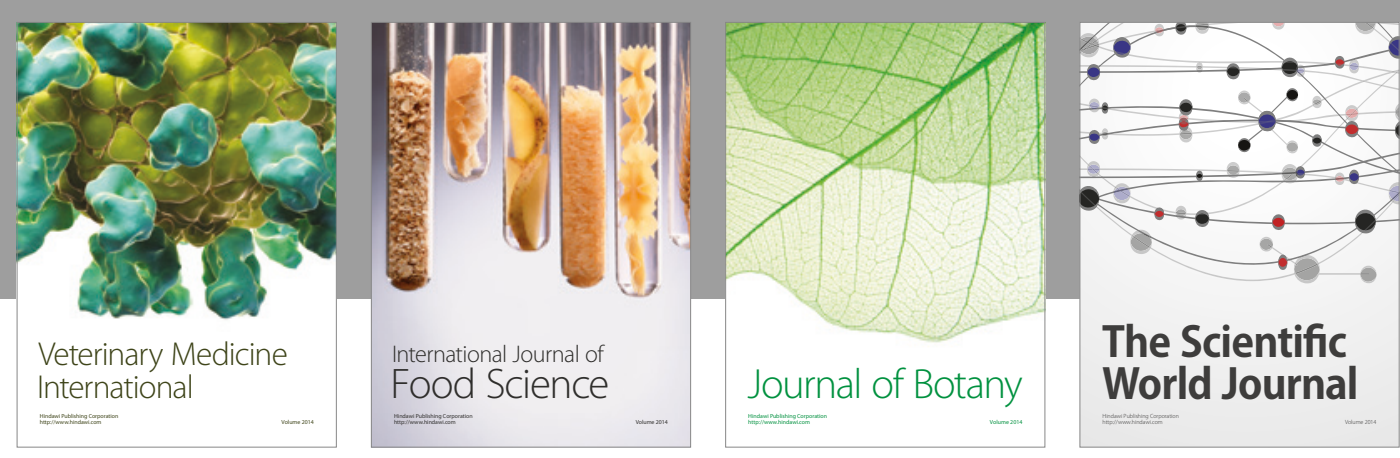

The Scientific

\section{World Journal}

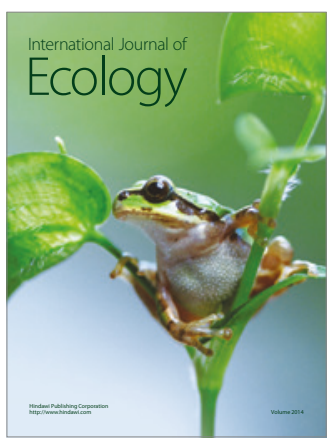

\section{Hindawi}

Submit your manuscripts at

https://www.hindawi.com
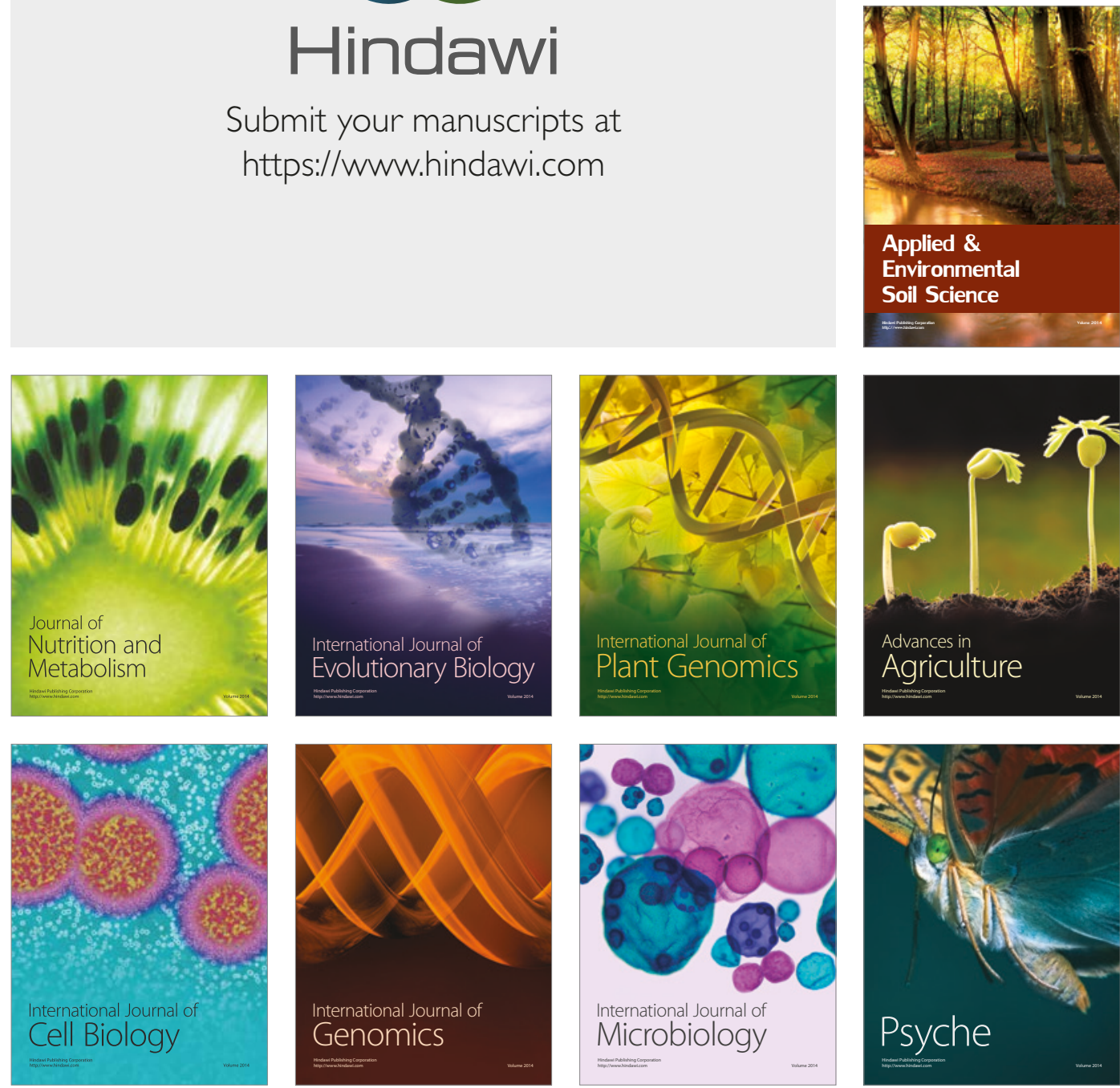

hternational Journal of Microbiology
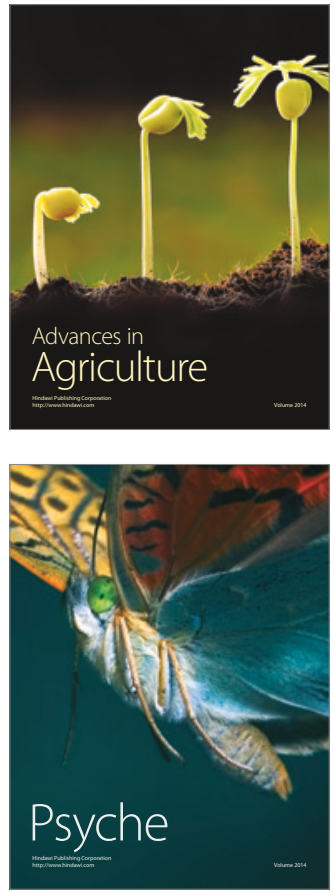